University of Nebraska - Lincoln

DigitalCommons@University of Nebraska - Lincoln

June 2008

\title{
Circular and Cumulative Causation and the Social Fabric Matrix
}

F. Gregory Hayden

University of Nebraska - Lincoln, ghayden1@unl.edu

Follow this and additional works at: https://digitalcommons.unl.edu/cbafacpub

Part of the Business Commons

Hayden, F. Gregory, "Circular and Cumulative Causation and the Social Fabric Matrix" (2008). College of Business Faculty Publications. 16.

https://digitalcommons.unl.edu/cbafacpub/16

This Article is brought to you for free and open access by the Business, College of at DigitalCommons@University of Nebraska - Lincoln. It has been accepted for inclusion in College of Business Faculty Publications by an authorized administrator of DigitalCommons@University of Nebraska - Lincoln. 


\title{
Circular and Cumulative Causation and the Social Fabric Matrix
}

\section{F. Gregory Hayden}

\begin{abstract}
This study combines the problem orientation of instrumentalism and the systems analysis of circular and cumulative causation (CCC) through the utilization of a social fabric matrix (SFM) and network digraph. The SFM is utilized to articulate part of the Nebraska State system used to distribute state funds among local K-12 public schools. The empirical content is used to derive conceptual conclusions about CCC and to make comments about a controversy regarding agents, institutions, and new rule development. This study provides a refinement of CCC, and it confirms that rules are not the result of self-action by agents.
\end{abstract}

Keywords: systems, networks, education, rules, agents

JEL Classification Codes: B52, D02, D85, H30, I22

Scientists from many different fields of study independently derived common principles about systems that are usually referred to as general systems analysis (GSA), which can be applied for analysis with the social fabric matrix (SFM) (see Hayden 2006, 51-60 and 94-106). The institutionalist Gunnar Myrdal used the term "circular and cumulative causation" (CCC) to describe principles he derived for the analysis of socioeconomic systems (1944, 1065-1070; 1974, 719-732; 1978, 774-775). His findings regarding systems were consistent with GSA discovered in other fields such as physics and biology. The purpose here is to present the SFM digraph in Figure 1 in order to use the empirical content of a real-world socioeconomic system to derive conceptual conclusions about CCC/GSA concerns, to include comments about current controversies. The SFM, digraph, and cellular description are completed for part of the Nebraska State system used to distribute state funds among local K-12 public schools. The Nebraska study combines the problem orientation of instrumentalism and the systems analysis of CCC/GSA. Figure 1 is a system taken from a larger whole consistent with the problem selected. The complete SFM study is available at the interactive SFM website (http://cba.unl.edu/academics/economics/ $\mathrm{sfm} /$ ).

The author is a Professor of Economics, at the University of Nebraska-Lincoln. This paper was presented at the annual meeting of the Association for Evolutionary Economics in New Orleans, LA, January 4-6, 2008. 
Figure 1. Social Fabric Matrix Digraph Components of Nebraska State Aid for a Local K-12 Public School, 2006-2007

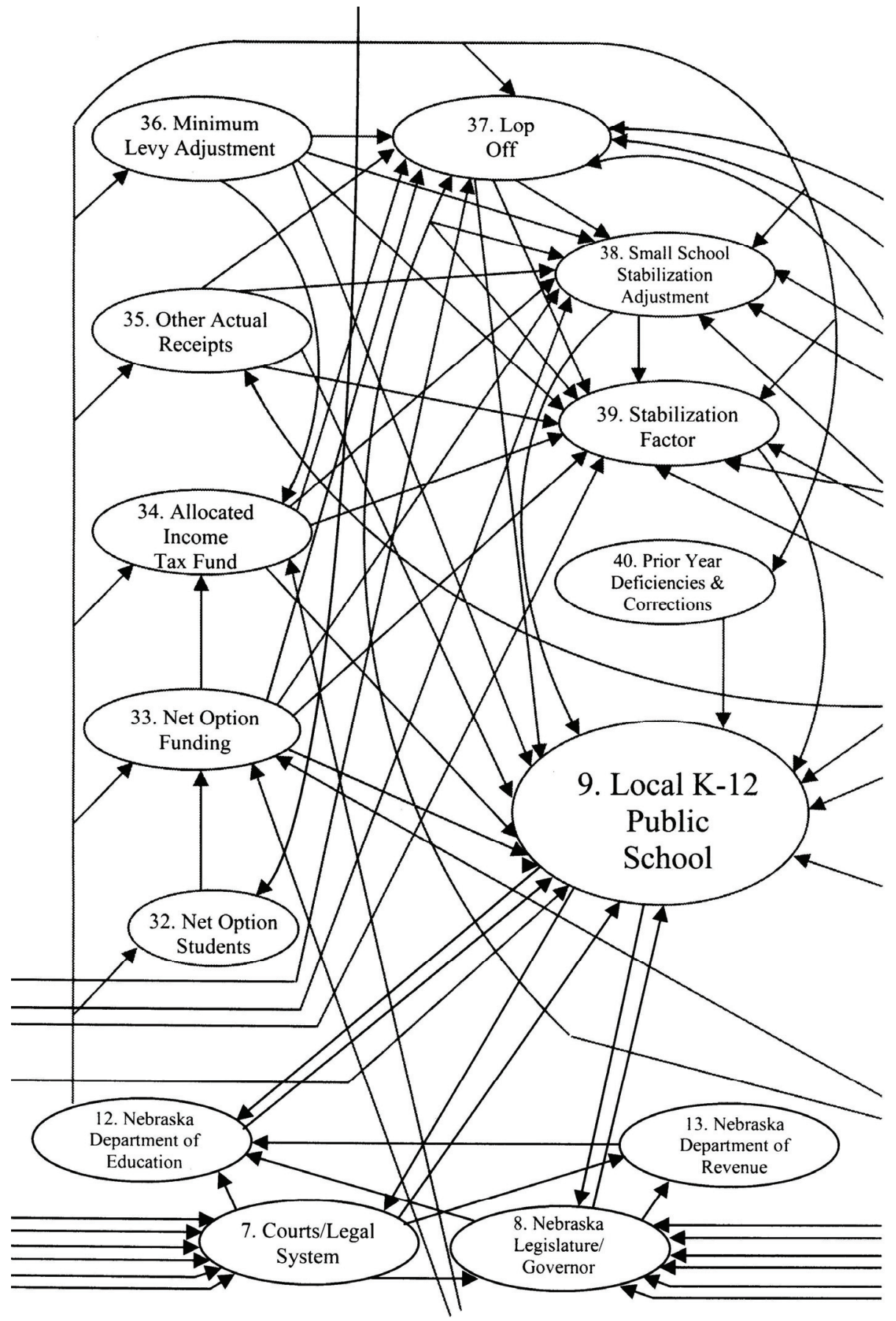


The main system for state school aid in Nebraska is titled the Tax Equity and Educational Opportunities Support Act (TEEOSA). The emphasis of the SFM study was to express the rules of TEEOSA that determine how much money is distributed by the state to each of the 257 school districts. The SFM cell descriptions are algebraic articulations of TEEOSA rules. These rules result in a continuous algebraic formula for each district that is 600 pages long (abridged to 138 pages in the website). The rules were discovered and converted to algebra by reviewing the laws, regulations, and standard operating procedures for each term and by interviewing and observing personnel in the departments and divisions responsible for calculating and programming the numbers that represent the amount of money that a district is to gain or lose from each term in the TEEOSA process. Government departments are the producers of the numbers, which are the work product in this case. Formula terms require the institutional organizations to coordinate work and data from the local, state, and federal government. The numbers produced and the use of those numbers - that is, the integrated work completed by these organizations - are determined by rules from the Nebraska Senate (Unicameral) and Nebraska Courts, as indicated in Figure 1.

As depicted in Figure 1, legislative and court decisions are delivered to the Nebraska Department of Education (NDE), which directs its divisions to follow the rules and to coordinate with other divisions and other departments in order to fulfill the regulations and requirements of the rules. The directed edges from NDE to the other components represent rules delivered to those components on what and how to calculate particular aspects of the overall formula, what data to use, from where to acquire it, and to what groups the calculations should be reported. The number preceding each component in Figure 1 is its SFM row and column number. Institutional components 32 through 39 are given the name that corresponds to TEEOSA rules that designate the components' activities. They are:

Net Option Students: Parents have the option of sending children to a school district in which they do not reside. Net option students for a district are the difference between the number of option students received from another district and the number of a district's option students going to another district. These students have already been counted once for the districts, but are counted again as net option students. According to the rules, the number of net option students compiled by the interaction of local districts and state personnel are directed to those who calculate net option funding (Neb. Rev. Stat. § 79-233). ${ }^{1}$

Net Option Funding: Net Option Funding is a long complicated formula term that is repeated numerous times throughout the formula. As evident in Figure 1, the term includes Net Option Students and components from outside the system. The amount of money calculated is added to the local district's fund, as indicated in the delivery edge between components 33 and 9. This term is beneficial to wealthy suburban districts that receive large numbers of students whose parents can afford to transport children from their home district in the 
city. As outlined in Figure 1, the rules require that the Net Option Funding formula terms be incorporated into the Allocated Income Tax Fund, Lop Off, Small School Stabilization Adjustment, and the Stabilization Factor (Neb. Rev. Stat. § 79-1009).

Allocated Income Tax Fund: The purpose of the Allocated Income Tax Fund is to distribute a special fund allocated from state income taxes among the 257 districts. The calculation includes formula terms from outside Figure 1 as well as the Net Option Funding and Minimum Levy Adjustment terms. Its findings are delivered to Lop Off, Small School Stabilization Adjustment, Stabilization Factor, and the local school districts. The Allocated Income Tax is both added to and subtracted from every school district; however, since the addition and subtraction take place in different sections of the formula, hold-harmless rules for some sections means the plus and minus of the same amount do not cancel each other for all districts (Neb. Rev. Stat. \$§ 79-1005.01 and 79-1005.02).

Other Actual Receipts: This is a list of federal, local, and state receipts for the local school districts that are subtracted from what a local district is to receive from TEEOSA. The majority of Other Actual Receipts is the same list of receipts designated as Special Receipts and added to part of the formula outside the system in Figure 1. Thus, the plus and minus of Special Receipts cancel each other and can be deleted from the formula without affecting district receipts. In addition to delivering its findings to indicate funding for local districts, Other Actual Receipts delivers its findings to Lop Off, Small School Stabilization Adjustment, and the Stabilization Factor (Neb. Rev. Stat. § 79 1018.01).

Minimum Levy Adjustment: This set of rules is applied to any local school district whose general fund property tax levy is less than 0.945. The calculated adjustment subtracts the local district's levy from 0.945 and multiplies the result by the adjusted valuations divided by 100. If the Minimum Levy Adjustment is greater than or equal to the Allocated Income Tax Fund, the local district shall not receive monies from the Allocated Income Tax Fund. Additionally, the Minimum Levy Adjustment organization delivers its calculations to Lop Off, Small School Stabilization Adjustment, and the Stabilization Factor (Neb. Rev. Stat. § 79-1008.02).

Lop Off: Lop Off affects only districts that receive equalization aid. It is a set of calculations designed to limit state aid. The term is long and complex because of all the components explained above that feed into it and because of calculations delivered from outside this system that are included. Lop Off is designed so that no local system may receive equalization aid when total state aid, added to a levy of 0.95 times the prior year's adjusted property valuation divided by 100 , exceeds numerous other calculated entities that are added together (for a list of 
entities, see Nebraska Department of Education 2006, 9). The Lop Off calculation is delivered to the local district, Small School Stabilization Adjustment, and the Stabilization Factor (Neb. Rev. Stat. § 79-1008.01).

Small School Stabilization Adjustment: This component calculates aid distribution to districts that have 900 or fewer formula students and adjusted operating expenditures per formula student less than the average for all such districts. The result of the calculation is delivered to the local district and the Stabilization Factor (Neb. Rev. Stat. § 79-1008.01).

Stabilization Factor: This factor is calculated so that a district shall not receive state aid which is less than the difference between 83.75 percent of the amount of aid certified in the preceding year minus an amount equal to 1.05 times any increase in the adjusted property valuation between the adjusted valuation used for the certification of aid in the preceding school fiscal year and the adjusted valuation used for the aid being calculated divided by 100 (Neb. Rev. Stat. § 79 . 1008.01).

\section{Findings for CCC/GSA}

The empirical base provided by Figure 1 allows for conceptual findings, as follows.

\section{Three Different Patterns of CCC}

The description of Figure 1 identifies three different patterns of CCC. The first is accumulation through the system. As the calculations are completed for each component, there is a continuous accumulation, as those calculations are transferred to other components. The second is the set of inputs from the environment surrounding the system, as indicated by the edges directed to components from outside the system. The third pattern of CCC, which was Myrdal's main concern $(1974,730)$, is due to changes made to components inside and/or outside the system. For example, if local school districts successfully petition courts (edge 9 to 7 in Figure 1) to change a rule or set of rules provided by the legislative body for distributing state aid, flows can change both within the system and the system's environment. Thus, it is invalid to assume a single kind of CCC pattern. It is also invalid to assume that cumulative causation is always circular. Some systems have delivered to surrounding environments for centuries without a return of circular impacts - soil erosion is an example.

\section{Numerous Deliveries to and from Components}

Consistent with complex systems, there are numerous deliveries to and from components. Abstract models in the system dynamics literature often indicate only one delivery to and from each component, often of an abstraction like a positive or 
negative sign. Such is not found in the real-world SFM in Figure 1. Abstract models in the literature about homeostatic control often have only one edge to each component without any specification about what is delivered among the institutional components. One delivery is assumed for coordination and control but, that is not the real-world case. There are numerous different kinds of deliveries in and out of institutional organizations and often different sources for the same kind of delivery. The main purpose and activity of an institution is to serve other institutions. Thus, the viability of that service depends on what is being delivered, the level being delivered, and how well it fits with other deliveries. A positive or negative sign is not accepted as a valid and sufficient delivery in a real-world institutional setting, for example in a school district.

\section{Individuals do not Structure the Rules or the System's Environment}

Humans serve in assemblies of cognitive agents in order to complete the roles necessary for the collective behavior of socioeconomic processes. Thus, a more appropriate term for humans than individuals ${ }^{2}$ might be homo nomos. As Robert Cover stated: "We inhabit a nomos - a normative universe. We constantly create and maintain a world of right and wrong, of lawful and unlawful, of valid and void" $(1984,4)$. The actors found in the Nebraska school finance system act according to Cover's explanation, not according to that of Douglass North. North stated that "institutions are the external (to the mind) mechanisms individuals create to structure and order the environment" $(1994,363)$. That is not consistent with reality. The discussion of Figure 1 clarifies that the workers and agents in the institutional components do not structure and order the environment outside the system. Neither do they order and structure the system itself nor its nomos. Those are created, delivered, regulated, and enforced by institutions - by the Nebraska Senate, courts, local school districts, NDE, and department divisions.

\section{Schumpeterian Destroyer Not Found}

Findings from the school finance case can be utilized to comment on a disagreement regarding the emergence of new rules and systems.

Kurt Dopfer, John Foster, and Jason Potts (DFP) stated: "Rules are the building-blocks of systems that form the micro-structure, or organization, of an economic system" $(2004,267)$. This leads DFP to be interested "in the micro analysis of agents originating and adopting rules, and the complex structures that arise ..." (269) as a result. That process creates change because of the "interactions of agents as they adopt and use rules" (269). The agent is a Schumpeterian creator and, thereby, a destroyer of the initial order as the "agent originates, adopts, adapts, and reclaims a novel generic rule" (269). For DFP, this creative destruction and concomitant "economic evolution is a process of change in rules and rulesystems" (271). It's "origination is where an agent develops an idea/rule that leads to the design of an organization ..." (271). This is a case of "the Schumpeterian ... 
entrepreneur acting imaginatively ..." (273). "The first thing to happen in the micro domain is that an agent explores a new rule and its capabilities" (272). Consequently, "we end up with a new micro organization . . ." (272). The new evolutionary trajectory "begins when an agent acquires, understands and imagines how to use a novel rule..." (272).

Wolfram Elsner expressed a concern about theories based on an "isolated Schumpeterian agent" (2008, forthcoming). He explained that DFP assume that the "originator of a new rule, however, appears to be some isolated Schumpeterian creative inventor ..." (2008) and that the "creative destroyer has the ideas for the rule and he/she continually explores new ideas because the mind is restless" (2008).

Elsner's disagreement draws, in part, on the criticism of others who have explained that DFP fail to (1) take account of the fact that the design of and decisions about rules must be coordinated with a multiplicity of actors in a network of institutions located across overlapping systems and (2) recognize that there will be different decision processes for rule innovation in different problem contexts (2008). Elsner's own concerns are: First, changing systems "involve changes of the structure of incentives to search, explore, experiment or imitate . .." (2008) with which the agent would have to deal rather than remain isolated in a fixed setting. Second, the social rule not only has to be traced back to a defined complexity but also to uncertainty problems, which have to be solved collectively (2008). Third, institutions, as opposed to the adoption of rules by an entrepreneur in a micro context, "are used to solve coordination problems and thus carry new and jointly learned knowledge, however informal and tacit" (2008).

The case of the Nebraska school finance system is inconsistent with the contentions of DFP. It is a system of overlapping institutions and organizations that are coordinated by laws, court decisions, regulations, monitoring, audits, media scrutiny, and so forth. Changing conditions are responded to by institutional procedures as new rules are designed, challenged, lobbied by adverse interests, tested, litigated, and adopted in a dynamic setting through the transactions of components of different systems. As found in the school aid case, explicit procedures and actions are taken to prevent any actor with an entrepreneurial inkling from changing rules that are codified by the whole process.

Recognition of CCC/GSA means the primary unit of analysis should be the components of the social fabric matrix. Agents (with agency power) are contained in institutional components. Too often, in economic literature, agents are defined and treated like individuals. An agent is not an individual. An agent is a person or party authorized and empowered by a principal to act in defined capacities. Agency is bestowed by the establishment of a relationship based on an understanding between persons and/or parties for an agent to act. Agents are not isolated or separate units because agency agreements are concerned with accountability, auditing, and performance. Most agents are institutional organizations (corporations, government departments, nonprofit organizations) that obtain agency status from other organizations. When persons are given agent responsibilities, they are located in an 
institutional organization and deal with a nomos.

DFP stated that "the agent has a mind" (2004, 269). First, an institutional organization such as a corporation does not have a mind. Second, persons involved have minds, not a mind. Persons given responsibilities in an institutional organization transact with other persons in that organization and with those in other organizations, some of whom are located in other systems, so the agency function is a multi-system assembly of the knowledge, skills, and cognitive capabilities that are coordinated to perform the agency function. "Thinking is a social activity" (Menand 2001, 431).

\section{Conclusion}

The Nebraska educational finance study illustrates how the SFM provides a methodology to utilize CCC/GSA and to further develop its principles. From such studies of real-world cases, we can continue to refine and develop socioeconomic concepts. This SFM application allows a refinement of our understanding of circular and cumulative causation patterns and of the definition of relationships among system components through deliveries. Furthermore, it confirms that the social prescriptions and proscriptions called rules are not the result of self-action by agents with fixed attributes.

\section{Notes}

1. All statutes cited, along with the relevant list of source laws, can be found at the Nebraska Legislative Documents website (see References).

2. Geoffrey Hodgson has demonstrated the continued popularity of ideas about rationality and individuals in the literature of economics (2007). Original institutional economists have documented that real-world cases are inconsistent with the model of rational individuals, as traditionally attributed by economists, and the behavioral economics literature documents that people do not have the ability to think that way. Humans are not rational (nor quasi- or semi-rational) and they are not individualized. The research completed for the finance system in Figure 1 discovered neither rational calculators nor individuals. In fact, persons given agency positions by institutions to conduct themselves according to Nebraska rules and regulations would be in serious trouble if they attempted to act in such a manner. For personnel to complete their tasks, the standard operating procedures of the bureaucracy are utilized, not the preferences and wants of personnel. Individual means indivisible and separate, and neither characteristic is demonstrated by those in the school finance system. Rather than indivisible and separate, a person is divided and the parts are very integrated with other system components and elements. An example is a person who is a professional accountant, consultant, active Catholic Altar Society member, wife, lobbyist, mother, family asset manager, Democrat, and Sierra Club member. For each activity, she has different roles, particularly in the government department for which she consults. She is further divided by the activities she undertakes because of the overlay of systems such as the oil cartel, global warming, and her country's wars. Personal divisibility is reality.

\section{References}

Cover, Robert M. "Foreword: Nomos and Narrative. "Harvard Law Review 97, 1 (November 1984): 4-68.

Dopfer, Kurt, John Foster, and Jason Potts. "Micro-meso-macro." Journal of Evolutionary Economics 14

(2004): 263-279. 
Elsner, Wolfram. "Why Meso? On 'Aggregation' and 'Emergence' and Why and How the Meso Level is Essential in Social Economics." Forum for Social Economics 37, 1 (April 2008): forthcoming.

Hayden, F. Gregory. Policymaking for a Good Society: The Social Fabric Matrix Approach to Policy Analysis and Program Evolution. New York; Springer, 2006.

Hodgson, Geoffrey. "The Revival of Veblenian Institutional Economics." Journal of Economic Issues 41, 2 (June 2007): 325-340.

Menand, Louis. The Metaphysical Club. New York: Farrar, Straus and Giroux, 2001.

Myrdal, Gunnar. American Dilemma: The Negro and Modern Democracy. New York: Harper and Row, 1944.

——. "What is Development?" Journal of Economic Issues 8, 4 (December 1974): 729-736.

"Institutional Economics." Journal of Economic Issues 12, 4 (December 1978): 771-783.

Nebraska Department of Education. Tax Equity and Educational Opportunities Support Act Certification of 2006-2007 State Aid. Lincoln: Education Support Services, February 2006.

Nebraska Legislative Documents. Revised Statutes. Chapter 79. Schools. http:// uniweb.legislature.ne.gov/legaldocs/view.php?page=index statutes (accessed July 16, 2007).

North, Douglass C. "Economic Performance through Time.” American Economic Review 84, 3 (June 1994): $359-67$. 